\title{
Enumeration and characterization of microorganisms in raw coir pith and coir pith dumped soil
}

\author{
Paramanandham, $\mathrm{J}^{1, *}$, a and P. Ronald Ross ${ }^{2, b}$ \\ ${ }^{1}$ Department of Zoology and Wildlife Biology, A.V.C College (Autonomous), Mannampandal, \\ Mayiladuthurai- 609 305. Tamil Nadu, India \\ ${ }^{2}$ Department of Zoology, Faculty of Science, Annamalai University. \\ Annamalai Nagar - 608 002, India. \\ a * paramusacon2010@gmail.com; br_ross1971@yahoo.co.in
}

Keywords: coir pith, microbes, vicinity, fluffy, dumping

\begin{abstract}
Coir pith is being considered as the reject generated during the extraction of coir fibre from coconut husks. It is a light weight and fluffy material with dusts and bits of fibres. The coir pith has many undesirable components and hence it does not carry any value addition. It needs to be degraded for the effective utilization for further activities. Microbes have the ability to decompose coir pith. Coir pith itself posses its own native microbes. Hence in the present study, raw coir pith and the soil dumped with coir pith in the dumping yards along the vicinity of the coir fibre factories were subjected for the enumeration and characterization of microorganisms. The coir pith for the study was collected from two locations in Cuddalore District. The results exhibited the presence of huge quantity of microbes in the raw coir pith than the coir pith dumped soil. Furthermore, the percentage occurrence of bacteria was significantly higher when compared with that of the fungi and actinomycetes. Totally 12 species of bacteria, six species of fungi and three species of actinomycetes were recorded. The results showed significant variation in the quantity and quality of the microbes.
\end{abstract}

\section{Introduction}

Coir pith, generally called as coco-peat, is a non-fibrous cottony material [1\} and it contains large quantities of lignocellulose [2]. It is dumped in huge piles on roadside and along the vicinity of the industries. Because of its high lignin, tannin and cellulose content and slow degradation in natural environment it leads to environmental pollution [3]. Microorganisms live in every part of the biosphere including soil, hot springs, on the ocean floor, high in the atmosphere and deep inside rocks within the Earth's crust. Microorganisms are crucial to nutrient recycling in ecosystems as they act as decomposers. Soil is made up of five major groups of microbial population including bacteria, actinomycetes, fungi, algae and protozoa, and among these groups, bacteria are the most abundant group [4] and the most important microbes for decomposing any waste.

Biological processes play a major role in the removal of contaminants and they take advantage of the astonishing catabolic versality of microorganisms to degrade or convert such compounds [5]. In such case, microbial biodegradation of the wastes is generally considered to be a safe, effective and environmental friendly process [6]. In the present study, the microbial population inhabiting in raw coir pith and coir pith dumped soil collected from two locations were enumerated quantitatively and qualitatively.

\section{Materials and Methods:}

\section{Collection of coir pith}

The coir pith required for the investigation was collected from Coir society industry and Palani murugan coir fibre industry, Tsunami Nagar of Cuddalore district Tamil Nadu, India, which is about $1 \mathrm{~km}$ away from Cuddalore Town and $50 \mathrm{kms}$ away from the University campus. Specifically, the Palanimurugan coir industry is located near the seashore of around 300 meters. These coir industries supply high quality coir fibres to produce coir ropes for the home workers in 
and around Cuddalore Town and they have high hillocks of coir pith in the vicinity of the industries. While collecting the coir pith from the mounds, the surface layer of the mound to a depth of $15 \mathrm{cms}$ was scrapped and discarded. The fresh coir pith required for the work was then collected aseptically and was transported to the laboratory in polythene bags for further studies.

\section{Quantitative analysis of microbes}

In order to carry out quantitative analyses of microbes, the total microbial populations (bacteria, fungi and actinomycetes) were determined in the abovementioned samples by the following methods.

\section{Determination of total microbial populations}

One gram of sample was diluted in $100 \mathrm{ml}$ of sterile saline in a sterile conical flask. The flask containing the substrate was shaken thoroughly in a Vortex mixture for 5 seconds. Three sets of Nutrient Agar (NA) and MacConkey Agar (MA) plates for bacterial growth [7], three sets of Sabouraud Dextrose Agar (SDA) and Rose Bengal Agar (RBA) plates for fungal growth [8], and three sets of Actinomycetes Agar (AA) plates for actinomycetes growth [8] were used as substrates. The substrate inoculum in $0.01 \mathrm{ml}$ was spread on the surface of these media to estimate the number of bacterial, fungal and actinomycetes colonies. The bacterial plates were incubated at $37^{\circ} \mathrm{C}$ for 18 24 hours, $25^{\circ} \mathrm{C}$ to $37^{\circ} \mathrm{C}$ for $5-7$ days of incubation for fungal growth and $25^{\circ} \mathrm{C}$ to $35^{\circ} \mathrm{C}$ for $10-12$ days of incubation for actinomycetes. The different microbial colonies developing on the plates were estimated by counting. The number of colony forming unit (CFU) on the surface of the media was counted and expressed as CFU $\times 105 \mathrm{~g}-1$, according to the method described by Baron et al., [9].

\section{Qualitative analysis of microbes}

For the qualitative analysis of microbes, the sample was collected from the initial substrate. Species of fungus, bacteria and actinomycetes isolation from test samples were done according to the method described by Mackie and McCartney [10].

\section{Isolation of bacteria}

The bacteria were isolated from the culture medium by using the stain Gram's Iodine and Safranin. After staining process, the bacterial cell on the slide was photographed under the Nikon microscope. Biochemical characterization of bacteria isolates were determined by Cappuccino and Sherman [11].

\section{Isolation of fungi}

Fungal isolates were examined microscopically and macroscopically using the needle mouth technique. Their identification was performed according to the protocol of Cheesbrough [12].

\section{Isolation of actinomycetes}

Morphological features of the actinomycetes were studied by inserting sterile cover slips in the actinomycetes agar medium at an angle of $45 \mathrm{oC}$. Spore suspension of the actinomycetes was inoculated at the intersection of the medium and cover slip. The cover slips were observed under light microscope after incubation for one week at 37oC. Biochemical characterization of actinomycetes was determined by Cappuccino and Sherman [11].

\section{Results}

The microbial populations were quantified both in raw coir pith and coir pith dumped soil in two different places. The results showed the existence of huge quantity of microbes in both the raw coir pith samples and significantly lesser quantity in soils. Among the microorganisms, bacteria was high and actinomycetes was low. The study indicates the significance of coir pith character which 
has notable microbial content (Table 1). Comparatively sea shore sample has relatively low content of microbial populations. The ANOVA, $\mathrm{P}<0.05$ showed that there is significant difference in the mean count among the locations. Table 2 exhibits the percentage of microorganisms present in the coir pith and coir pith dumped soil in the two locations.

Table 1. The mean counts of microorganisms isolated from the two different locations $($ Mean \pm SD) (Six replicates):

\begin{tabular}{|l|l|l|l|}
\hline $\begin{array}{l}\text { Samples CFU/g of } \\
\text { Samples }\end{array}$ & Bacteria $\left(\mathbf{x 1 0}^{5}\right)$ & Fungi $\left(\mathbf{x 1 0}^{3}\right)$ & Actinomycetes (x10 \\
\hline SO & $15.61 \pm 1.89^{*}$ & $6.12 \pm 0.87^{*}$ & $3.86 \pm 1.53^{*}$ \\
\hline SY (Soil) & $9.56 \pm 1.24^{*}$ & $4.32 \pm 0.98^{*}$ & $2.61 \pm 1.34^{*}$ \\
\hline SS & $13.44 \pm 1.78^{*}$ & $4.83 \pm 1.67^{*}$ & $3.15 \pm 1.65^{*}$ \\
\hline SX (Soil) & $8.34 \pm 1.46^{*}$ & $2.74 \pm 1.65^{*}$ & $1.98 \pm 0.75^{*}$ \\
\hline
\end{tabular}

*Mean values are significant at 5\% level SNK (ANOVA)

SO- Society office coir pith

SY- Soil sample from society office

SS- Palanimurugan coir industry coir pith

SX- Soil Sample from palanimurugan industry

Table 2. Percentage occurrence of microorganisms

\begin{tabular}{|l|l|l|l|l|l|l|}
\hline Samples & \multicolumn{3}{|l|}{$\%$ of occurrence among microbes } & \multicolumn{2}{l|}{ \% of occurrence among samples } \\
& Bacteria & Fungi & Actinomycetes & Bacteria & Fungi & Actinomycetes \\
\hline & 61.00 & 23.92 & 15.08 & 33.24 & 33.98 & 33.27 \\
\hline SO & 57.97 & 26.19 & 15.82 & 20.36 & 23.98 & 22.50 \\
\hline SY (Soil) & 65.82 & 23.65 & 15.42 & 28.64 & 26.83 & 27.16 \\
\hline SS & 20.98 & 15.16 & 17.76 & 15.21 & 17.07 \\
\hline SX (Soil) & 63.85 & \multicolumn{3}{l}{} &
\end{tabular}

The percentage occurrence of bacteria was high in all the samples extensively and actinomycetes were low in all the samples. When the percentage occurrence of microbes was calculated, the coir pith from coir pith society showed the maximum occurrence of microbes. Table 3 reveals the different types (12 bacteria (table 4), 6 fungi and 3 actinomycetes) of microorganisms namely bacteria, fungi and actinomycetes that dwell in raw coir pith and coir pith dumped soil. In coir society coir pith sample, ten species of bacteria, six species of fungi and three species of actinomycetes were recorded. Eight species of bacteria, three species of fungi and two species of actinomycetes were notified in soil sample from the coir society. Palanimurugan coir industry coir pith sample exhibited nine species of bacteria, four species of fungi and three species of actinomycetes. Among the twelve species of microbes recorded in Palanimurugan coir industry soil sample, seven species were bacteria, three species fungi and two species were actinomycetes.

Table 3. The list of microbes present in the of raw coir pith and coir pith dumped soil from the two different locations

\begin{tabular}{|l|l|l|l|}
\hline Sampling & Bacteria & Fungi & Actinomycetes \\
\hline Coir Society (SO) & Escherichia coli & Aspergillus flavus & Streptomyces albus, \\
& Xanthomonas sp & A.nidulans, & Nocardia caviae \\
& Methylobacterium & A.niger, & Nocardia asteroids \\
& Acinetobacter sp & A.terreus, & \\
& Vibrio sp. & Penicillium citrinum & \\
& Enterobacter aerogenes & Fusarium oxysporum, & \\
& Pseudomonas fluorescens & & \\
& Pseudomonas aeruginosa & & \\
& Bacillus subtilis & & \\
& Proteus vulgaris & & \\
\hline
\end{tabular}




\begin{tabular}{|c|c|c|c|}
\hline $\begin{array}{l}\text { Coir Society (SX) } \\
\text { (Soil) }\end{array}$ & $\begin{array}{l}\text { Escherichia coli } \\
\text { Xanthomonas sp } \\
\text { Acinetobacter sp } \\
\text { Enterobacter aerogenes } \\
\text { Pseudomonas fluorescens } \\
\text { Bacillus subtilis } \\
\text { Bacillus cereus } \\
\text { Klebsiella pneumonia }\end{array}$ & $\begin{array}{l}\text { Aspergillus flavus } \\
\text { A.nidulans, } \\
\text { A.terreus }\end{array}$ & $\begin{array}{l}\text { Streptomyces albus, } \\
\text { Nocardia caviae }\end{array}$ \\
\hline $\begin{array}{l}\text { Palanimurugan } \\
\text { coir industry (SS) } \\
\text { (CP) }\end{array}$ & $\begin{array}{l}\text { Escherichia coli } \\
\text { Xanthomonas sp } \\
\text { Methylobacterium } \\
\text { Acinetobacter sp } \\
\text { Enterobacter aerogenes } \\
\text { Pseudomonas fluorescens } \\
\text { Pseudomonas aeruginosa } \\
\text { Bacillus subtilis } \\
\text { Bacillus cereus }\end{array}$ & $\begin{array}{l}\text { Aspergillus nidulans, } \\
\text { A.terreus, } \\
\text { Fusarium oxysporum, } \\
\text { Penicillium citrinum }\end{array}$ & $\begin{array}{l}\text { Streptomyces albus, } \\
\text { Nocardia caviae } \\
\text { Nocardia asteroids }\end{array}$ \\
\hline $\begin{array}{l}\text { Palanimurugan } \\
\text { coir industry (SY) } \\
\text { (Soil) }\end{array}$ & $\begin{array}{l}\text { Escherichia coli } \\
\text { Xanthomonas sp } \\
\text { Acinetobacter sp } \\
\text { Enterobacter aerogenes } \\
\text { Methylobacterium } \\
\text { Pseudomonas fluorescens } \\
\text { Bacillus subtilis }\end{array}$ & $\begin{array}{l}\text { Aspergillus flavus } \\
\text { A.terreus, } \\
\text { Penicillium citrinum }\end{array}$ & $\begin{array}{l}\text { Streptomyces albus, } \\
\text { Nocardia asteroids }\end{array}$ \\
\hline
\end{tabular}

Table 4. Biochemical characterization of bacterial isolates

\begin{tabular}{|c|c|c|c|c|c|c|c|c|c|c|c|}
\hline $\begin{array}{l}\dot{Z} \\
\dot{n}\end{array}$ & 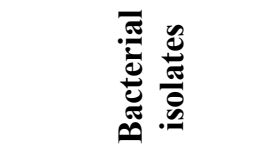 & 芳芯 & : & $\frac{0}{\frac{0}{0}}$ & 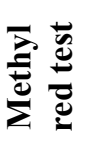 & 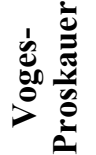 & 苞 & 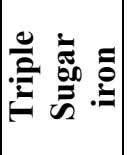 & Ũ & $\frac{0}{0}$ & 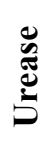 \\
\hline 1 & Escherichia coli & - & + & + & + & - & - & + & + & - & - \\
\hline 2 & Xanthomonas sp & - & + & - & - & - & + & + & + & - & - \\
\hline 3 & Methylobacterium & - & + & - & - & - & + & + & + & - & + \\
\hline 4 & Acinetobacter sp & - & - & - & - & - & + & - & + & - & - \\
\hline 5 & Vibrio sp. & - & + & + & + & + & + & + & + & + & - \\
\hline 6 & $\begin{array}{l}\text { Enterobacter } \\
\text { aerogenes }\end{array}$ & - & + & - & - & + & + & + & + & - & - \\
\hline 7 & Proteus vulgaris & - & + & + & + & - & - & + & + & - & + \\
\hline 8 & $\begin{array}{l}\text { Klebsiella } \\
\text { pneumonia }\end{array}$ & - & - & - & - & + & + & + & + & - & - \\
\hline 9 & $\begin{array}{l}\text { Pseudomonas } \\
\text { fluorescens }\end{array}$ & - & + & - & - & - & + & - & + & + & - \\
\hline 10 & $\begin{array}{l}\text { Pseudomonas } \\
\text { aeruginosa }\end{array}$ & - & + & - & - & - & + & - & - & + & + \\
\hline 11 & Bacillus subtilis & + & - & - & - & - & - & + & + & + & - \\
\hline 12 & Bacillus cereus & + & - & - & - & - & - & + & + & + & - \\
\hline
\end{tabular}




\section{Discussion}

The results of the present study fall in line with the works of Adesemoye et al.[13] and Ezeronye and Ubalua [14]. Bartha and Atlas [15] reported that when natural environments are contaminated with pollutants the indigenous microbial communalities are likely to contain microbial populations of different taxonomic characteristics which are capable of degrading the contaminating waste. They are autochthonous microbial communities and have the potential of waste degradation [16]. Gram negative bacteria were dominant in the genera of the bacteria isolated from both the samples from both the places. This was in accordance with the results of Daboor [17] which reported the prevalence of microbes in fish farm soil. Among all the groups, the highest countable microorganisms were present in coir pith sample from coir society and low in soil sample from Palanimurugan coir industry. It is presumed that, higher salinity could have been the major attribute for the low quantity and quality of microorganisms. Similar results have been documented by several authors in different wastes and waste waters $[18 ; 19 ; 20]$.

\section{Conclusion}

From the present investigation, it is well evident that coir pith has unique property to accommodate microorganisms significantly. The coir pith dumped soil has lesser amount of microbial population because their properties may be less congenial than the coir pith for the effective survival of microbes. Moreover, the coir pith dumped soil might have been rich in the native toxic elements present originally in coir pith because the leachate from the coir pith during monsoon seasons would have contaminated the soil with abundance of tannin, lignin, cellulose and pectic substances and thus creating an unconducive environment for the natural growth of microbes in the coir pith dumped soil. Whereas the microbes inhabiting the matrix of coir pith have the characteristic property of degrading the above toxic constituents as a function of time. This microbial degradation in due course may enhance the microbial population which could be reflected in the suitability of subjecting coir pith as an effective substrate for the growth of vegetable crops, ornamental plants and forest nurseries at large. Further studies may be required to study the micro and macronutrients status in coir pith in order to design and evolve a better culture medium from coir pith.

\section{Acknowledgements}

The authors gratefully thank the University Grants Commission, Govt. of India, for the financial support rendered to execute this project and the authorities of Annamalai University for their kind gesture that enabled to carry out this work and publish the findings.

\section{References:}

[1] Bhowmic BB and Debnath CR. Coir fibre, Part II. Potentiality of coir fibre products. Indian Cocon J 1985; 16(3): 7-10.

[2] Savithri P and Khan H. Characteristics of coconut coir pith and its utilization in agriculture. J Plantn Crops 1994; 22(1): 1-13.

[3] Bhat AD and Narayan P. Chromatographic Analysis of phenolics and study of Klason lignin biodegraded coir pith using "Pleurotus sajor caju" [dissertation], 2003; University of Kerala, Alappuzha.

[4] Alexander M. Introduction to Soil Microbiology, John Wiley and Sons: Inc, New York: 1961.

[5] Madigan MT and Martinko JM. Brock biology of microorganisms. 11th edition, Prentice Hall International Ltd, USA: 2003; p. $78-89$.

[6] Vijaya D, Padmadevi SN, Vasandha S, Meerabhai RS, Chellapandi P. Effect of vermicomposted coir pith on the growth of Andrographis paniculata. J Org Syst 2008; 3: 5156. 
[7] Anonymous A. Difo manual of dehydrated culture media and reagent for microbiological and clinical laboratories. Detriot; Michigan: 1977.p.350.

[8] Emmon CW, Binford CH, Utz JP. Medical Mycology 2nd edition, Hendry Kimpton, 464, London: 1970.

[9] Baron JE, Peterson RL, Finegold MS. Cultivation and isolation of viable pathogens. In: Diagnostic Microbiology. 9th edition; Chap. 9; Mosby: London: 1994. p.79-96.

[10] Mackie and McCartney. 'Practical Medical Microbiology', 13th edition, Kalyani Publishing Co: New Delhi: 1989.

[11] Cappuccino JG and Sherman N. A laboratory Manual of Microbiology, Rock land Community College, Suffern, New York: 1999.

[12] Cheesbrough M. District Laboratory Practice in Tropical Countries. Cambridge University Press:United Kingdom: 2005. p. 30-41.

[13] Adesemoye AO, Opere BO, Makinde SCO. Microbial content of abattoir wastewater and its contaminated soil in Lagos, Nigeria, Afri J Biotech 2006; 5(20):1963-1968.

[14] Ezeronye OU and Ubalua AO. Studies on the effects of abattoir and industrial effluents on the heavy metals and microbial quality of Aba River in Nigeria, Afri J Biotechnol 2005; 4(3): 266 $-272$.

[15] Bartha R and Atlas RM. The Microbiology of Aquatic oil Spills. Adv Appl Microbiol 1977; 22: $225-226$.

[16] Eze VC and Okpokwasili GC. Microbial and other related changes in a Niger Delta River sediment receiving industrial effluents, Continent. J Microbiol 2010; 4: $15-24$.

[17] Daboor SM. Microbiological Profiles of El- Qanater El-Khairia Fish Farm. Global Veterinarian 2008: 2(2):51-55.

[18] Kasthuri J, Cholarajan A, Vijayakumar R, Muthukumaran P. Physico-chemical and microbial analysis of coir industry effluent. Asian J Res Pharm Sci 2011; 1: 44-46.

[19] Eze VV and Ikeri EP. Enumeration and characterization of microorganisms involved in the degradation of Abattoir waste in Portharcourt. Int J Cur Res 2010; 6: 53-57.

[20] Eze VC and Ogbaran IO. Microbiological and physicochemical characteristics of fish pond water in Ughelli, Delta State, Nigeria. Int J Cur Res 2010; 8: 82-87. 